
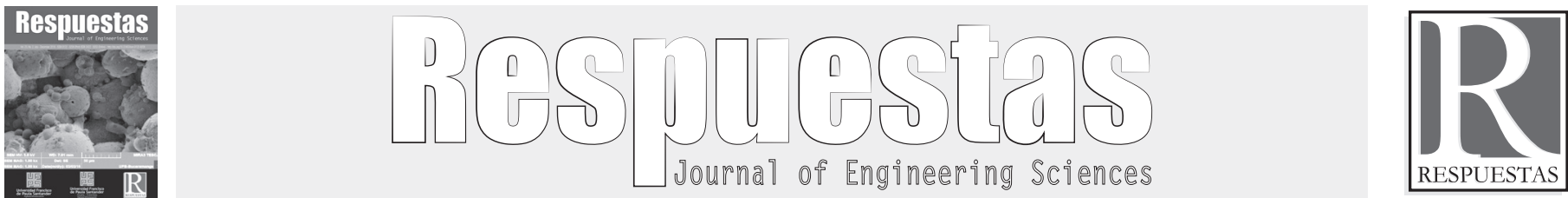

Original Article

https://doi.org/10.22463/0122820X.1741

\title{
Study of the carbon footprint in a ceramic production process in the metropolitan area of Cucuta
}

Estudio de la huella de carbón en un proceso productivo cerámico en el área metropolitana de Cúcuta

Leidy Katherine Peñaloza-Isidro ${ }^{*}$, Oscar Orlando Ortiz-Rodríguez², Jorge Sánchez-Molina ${ }^{3}$

${ }^{1 *}$ Magíster (C) en Ingeniería Industrial, leidyisidro06@gmail.com, Orcid: 0000-0002-6711-995X, Universidad de Pamplona. Pamplona, Colombia.

${ }^{2}$ Doctor en Ingeniería Química, Ambiental y de Procesos, oscarortiz@unipamplona.edu.co, Orcid: 0000-0003-2250-9804, Universidad de Pamplona.Pamplona, Colombia

${ }^{3}$ Doctor en Ingeniería de los Materiales y Energías Sostenibles, jorgesm@ufps.edu.co, Orcid: 0000-0002-9080-8526, Universidad Francisco de Paula Santander. Cúcuta, Colombia.

How to cite: L.K. Peñaloza-Isidro, O.O Ortiz-Rodríguez, J. Sánchez-Molina, "Study of the carbon footprint in a ceramic production process in the metropolitan area of Cucuta", Respuestas, vol. 23, no. 2, pp. 89-95, 2018

Received on January 29, 2018 Approved on May 11, 2018.

ABSTRACT

Keywords:

Clay; Ceramic

Product, Carbon

Footprint,

Thermoelectric

Ashes, Norte de

Santander
The experimental process was proposed in order to establish the viability of substituting part of the mineral fraction used at present (clayey material) by residues of combustion processes (ashes) of coal in thermoelectric, as an element to reduce the carbon footprint of the process of production of ceramic products, without altering the quality, properties and functionality of the final product. The study focuses on the specific case of a brick-making company in the metropolitan area of Cúcuta, and on the substitution of $10 \%$ of the raw material (clay) for ashes from the thermoelectric plant, for the production of ceramic blocks. The analyses carried out establish an energy saving derived from the use of $10 \%$ fly ash equivalent to $997.12 \mathrm{Kg}$ of Norte de Santander coal per burn. The results determine that, in the case of brick production, the annual reduction of emissions associated with the production process, with the use of ashes from the thermoelectric, would be 849.48 tons of $\mathrm{CO}_{2}$. Thus, the carbon footprint is reduced by $16.39 \mathrm{kgCO}_{2}$ equiv/t finished product, which represents a decrease of $5.99 \%$ of the carbon footprint compared to the conventional process.

\section{RESUMEN}

\section{Palabras clave:}

Arcilla; Producto

Cerámico, Huella

de Carbono,

Cenizas de

Termoeléctrica,

Norte de Santander
El proceso experimental fue propuesto a fin de establecer la viabilidad de sustituir parte de la fracción mineral usada en la actualidad (material arcilloso) por residuos de procesos de combustión (cenizas) de carbón mineral en termoeléctrica, como elemento para reducir la huella de carbono del proceso de producción de productos cerámicos, sin alterar la calidad, propiedades y funcionalidad del producto final. El estudio se centra en el caso concreto de una empresa ladrillera del área metropolitana de Cúcuta, y en la sustitución de un $10 \%$ de la materia prima (arcilla) por cenizas procedentes de la central termoeléctrica, para la producción de bloque cerámico. Los análisis realizados establecen un ahorro energético derivado del uso de un $10 \%$ de ceniza volante equivalente a $997.12 \mathrm{Kg}$ de carbón de Norte de Santander por quema. Los resultados determinan que, para el caso de la producción de la ladrillera, la reducción anual de emisiones asociadas al proceso productivo, con el uso de cenizas de la termoeléctrica, sería de 849.48 toneladas de $\mathrm{CO}_{2}$. Así, la huella de carbono se ve reducida en $16.39 \mathrm{kgCO}_{2}$ equiv/t producto acabado, lo que supone un descenso de un 5,99\% de la huella de carbono respecto del proceso convencional. 


\section{Introduction}

At a global level, awareness of the importance of environmental protection is growing. Global warming and high generation of waste from industrial and commercial activity are topics that are the subject of research in different parts of the world. $[1],[2],[3],[4]$.

The circular economy is a reality more and more present, driving the productive sectors to consider alternatives that promote the conservation of the environment, and to face the shortage of productive and energy resources [5]. The circular economy model gives value to waste, regardless of whether it is organic or technological, based on the intelligent reuse of waste in a cyclical model, converting it into raw material for the manufacture of new technological products [6], [7], [8]. The circular economy arises mainly in the literature through two principles called 3R: Reduce, Reuse, and Recycle; and 6R: Reuse, Recycle, Redesign, Remanufacture, Reduce and Recover [9]. The circular economy is considered a solution to harmonize these needs for economic growth and environmental protection

The ceramic industry is a large consumer of energy and natural resources, necessary to produce ceramic construction products, therefore it is also a major generator of greenhouse gases such as carbon dioxide, which is mainly due to the oxidation of fuels in ovens during the firing process [10].

This research has focused on the use of an abundant technological nutrient in the metropolitan area of Cucuta, such as fly ash from thermoelectric plants. A previous study [11] has shown the technical feasibility of replacing $10 \%$ of clays with fly ash in the manufacture of ceramic products, giving rise to products with technological properties in accordance with current regulations. The study carried out aims to demonstrate the environmental viability of the use of fly ash. The energetic and environmental effects of technological nutrient (fly ash) presence in the ceramic material are valued through carbon footprint calculation, through a comparative analysis of the conventional product with respect to the new alternative product, which uses $10 \%$ by mass of fly ash as a partial substitute for clay, in order to perform an environmental validation of a product already validated at a technological and functional level.

\section{Materials and Methods}

The calculation of the Carbon Footprint (CF) is done following the methodology described in PAS 2050 [12] and ISO 14067 [13]. Once the process map has been defined (stage 1), the most relevant study parameters are selected within product environmental information. The scope and limits of the system are determined, also setting the parameters to study (stage 2) and proceeds to collect all the necessary information to obtain as much data as possible to achieve the proposed objectives (stage 3 ).

The nutrient free production process is compared when $10 \%$ fly ash is included in the process [14].

\section{Construction of the map of processes}

The processes of the cycle of life, with generic character, of the ceramic product object of the present investigation, can be summarized in the following: Extraction of raw materials (A1), Transport of raw materials to plant (A2), Grinding (A3a), Molding (A3b), Drying (A3c), Firing (A3d), Classification and packaging (A3a), Transport to final destination, Commissioning, Maintenance of the building, Demolition of the building (end of life), and Treatment of the waste at the end of the useful life. In accordance with the requirements of the regulations applied in this study, when making the calculation of the Carbon Footprint it is necessary to follow certain rules, requirements, and specific guidelines, compiled in the Product Category Rules (PCR) [15]. The European Association of Manufacturers of Ceramic Products "TBE", has published the document "TBE PCR for clay construction products: A Guidance document for developing an EPD [16]". In the absence of specific CPR for structural ceramic products in Colombia, (beyond the indications of the Colombian environmental seal) [17], the rules set out in Standard EN-15084 are followed in the present comparative analysis [18]. Similarly, the PCR developed by TBE and the PCR developed internationally for ceramic products are taken as reference. 
Based on these indications, the declared unit is referred to as "ton of manufactured ceramic product", in this specific case, refers to a ton of ceramic block produced in brickwork.

\section{Inventory analysis}

\section{Clay extraction data (A1)}

This stage only considers the impact associated with fuel consumption used by the extraction machinery (petrodiesel), leaving the rest of the elements out of the study, interpreting a priori, that the impact produced by them will be minimal in relation to the total load of the product studied (e.g. maintenance oils for machinery or tires). The most relevant consumption data collected, in the clay extraction plant, related to the extraction of clays as raw material for the manufacture of ceramic products are the following: Extraction machinery, consumptions (petrodiesel) and yields: Excavator: 6.6gal/h (24.98 1/h) and 66Ton/h; Bulldozer: 4.8gal/h (18.161/h) and 66Ton/h; Loader: 2.04gal/h (7.721/h) and 144Ton/h; Caterpillar: 3.6gal/h (13.631/h) and 36Ton/h.

\section{Data of fly ash generating plant (A1)}

For the comparative study, the most relevant consumption data collected in this plant, related to the technological nutrient, are those related to the process of loading the product in trucks for transport to the ceramic production plant of the brickyard. Machinery of load, consumptions (petrodiesel) and efficiencies: loaders: $2.04 \mathrm{gal} / \mathrm{h}(7.721 / \mathrm{h})$ and 144.00Ton/h

\section{Transport of raw materials to production plant (A2).}

According to the information collected, and in order to compare both the clay taken from the mine and the ashes collected from the thermoelectric plant, a dump truck is considered, with the following technical characteristics: Volume: $18.00 \mathrm{~m} 3$, Maximum payload: 2.00t, Maximum engine power: $240.00 \mathrm{Kw}$, Average displacement speed: $40 \mathrm{~km} / \mathrm{h}$, Average consumption 100km: 10.30gal (38.991), Distance (mine - brickyard): $22 \mathrm{~km}$. The round trip is considered since the return route cannot be used by trucks to load another type of product.

\section{Ceramic production (A3).}

The data collected in the brickyard, for each of the stages of the production process, are the following:

- Storage, loading, and grinding. Corresponding to the consumption of the loaders, which is $2.04 \mathrm{gal} / \mathrm{h}$ $(7.72 \mathrm{l} / \mathrm{h})$ and a yield of $144 \mathrm{Ton} / \mathrm{h}$. In the milling process, hammer mills and conveyor belts are used. The energy consumed in this stage is of electrical origin, being the consumption of $10800 \mathrm{~kW} / \mathrm{h}$, with a yield of $4.13 \mathrm{kWh} / \mathrm{t}$..

- Molding and extrusion. The machinery used in this phase are mixers, laminators, extruders, and cutters. The electric power consumed in this stage is $6.92 \mathrm{kWh} / \mathrm{t}$.

- Dried. The energy consumed in this stage, of electrical origin, is $180 \mathrm{Kwh} / \mathrm{t}$.

- Firing. In the firing operation, flame-type beehive ovens with a capacity of 180.00 tons of product fired by burning are used. The electricity consumption is $10.80 \mathrm{kWh} / \mathrm{t}$

- Classification and packaging. The machinery used in this stage is a heat shrinkable packaging tunnels, with an electrical consumption of 2.82 $\mathrm{kWh} / \mathrm{t}$.

\section{Results and discussions}

\section{Impact evaluation Calculation of the carbon footprint}

For impacts evaluation, the following operation conditions facilitated by the brickwork have been taken into account: Firing at $900{ }^{\circ} \mathrm{C}, 30,000$ blocks loaded to a hive type oven, Approximate weight of a fired block $6.0 \mathrm{~kg}, 15$ ton of mineral coal used for the firing Energy saving derived from the use of $10 \%$ flying ash: $997.12 \mathrm{Kg}$ of coal per burning [1]. The inputs obtained in the inventory phase are converted into environmental charges ( $\mathrm{CO}_{2}$ equiv), making the corresponding mass balances for each phase of the process, and applying the corresponding internationally accepted emission factors. 
Regarding the emission factors, within the framework of the project Mechanism of Voluntary Mitigation of Greenhouse Gases Colombia -MVC-, carried out by Fundación Natura, La Bolsa Mercantil, and La Corporación Ambiental Empresarial, with the accompaniment and coordination of Colombian UPME and MADS, a technical consultancy was developed to update the database of the Emission Factors of Colombian Fuels -FECOC [13]. The emission factors used in the present study are the following: ACPM (petrodiesel): $10.28 \quad \mathrm{kgCO}_{2} /$ gallon $\left(2.95 \mathrm{kgCO}_{2} / \mathrm{t}\right)$, Thermal coal from Norte de Santander: $2812.75 \mathrm{kgCO}_{2} /$ ton.

For the calculation of the emissions derived from the production, transport, and consumption of electric power, in 2016 the indicator of $\mathrm{CO}_{2}$ equiv emissions per kWh of electrical energy consumed was 120 grams of $\mathrm{CO}_{2}$ per $\mathrm{kWh}$ consumed.

\section{Carbon footprint (CF) in the conventional manufacturing process.}

The total $\mathrm{CF}$ for the conventional manufacturing process is defined by the following formula and applies to clay as a technological nutrient:

\section{$C F($ total $)=C F(A 1)+C F(A 2)+C F(A 3 a)+C F(A 3 b)+C F(A 3 c)+$ $C F(A 3 d)+C F(A 3 e)$}

Where: CF (total) is the total carbon footprint of the product $\left(\mathrm{kgCO}_{2}\right.$ equiv/t finished product), the addendums being the $\mathrm{CF}$ of each of the stages: $\mathrm{CF}$ (A1) refers to the extraction of raw materials (clay in mines and technological nutrient in thermoelectric); $\mathrm{CF}$ (A2) transporting raw materials to plant; $\mathrm{CF}$ (A3a) storage, loading and grinding; $\mathrm{CF}$ (A3b) Molding; CF (A3c) Drying; CF (A3d) Firing; CF (A3e) Classification and packaging.

Calculating $\mathrm{CF}$ of each of the sub stages:

- Extraction of raw materials. Mines (A1). Calculated from the consumptions of the extraction machinery, and yields of them, obtained in the inventory phase: Excavator: $0.1000 \mathrm{gal} /$ ton $(0.3785$ 1/t), Bulldozer: $0.0727 \mathrm{gal} / \mathrm{t}(0.2752 \mathrm{l} / \mathrm{t})$, Loader: $0.0142 \mathrm{gal} / \mathrm{t}(0.0536 \mathrm{l} / \mathrm{t})$, Dump truck: $0.1000 \mathrm{gal} / \mathrm{t}$ $(0.37851 / t)$.
A total unit consumption of $0.29 \mathrm{gal} / \mathrm{t}(1.09 \mathrm{l} / \mathrm{t})$ of extracted clay is obtained: $\mathrm{CFA} 1=$ unit consumption $*$ emission factor $=2.95 \mathrm{~kg} \mathrm{CO}_{2}$ equiv/t. Referred to ton of clay (raw material) extracted.

\section{- Transport of raw materials to production plant} (A2).

$$
\text { Unit Consumption }\left(\frac{l}{t}\right)=\frac{C v * D}{2 * C t}
$$

Where: $\mathrm{Cv}=$ Transport vehicle consumption $(1 / \mathrm{km})$, $\mathrm{Ct}=$ Transport vehicle load $(\mathrm{t}), \mathrm{D}=$ Distance traveled from the quarry to the plant, 2 = Fixed factor (when considering the round trip).

For the precise calculation for each case, the three indicated variables should be considered. Therefore: CF A2 $=$ consumption $(1 /$ ton $* \mathrm{~km}) *$ (distance $(\mathrm{km}) * 2) *$ emission factor $(\mathrm{kg} \mathrm{CO}$ equiv $/ \mathrm{l})=1.94$ $\mathrm{kgCO}_{2}$ equiv/t. Referred to ton of clay (raw material) transported

\section{- Product manufacturing (A3)}

\section{Storage, loading and grinding (A3a).}

$$
C F A 3 a=(C e * F e e)+(C c * F e c)
$$

Where: Ce: Unit electricity consumption, Fee: Electricity emission factor $\left(\mathrm{kgCO}_{2} / \mathrm{kWh}\right), \mathrm{Cc}$ : Fuel unit consumption, Fec: Fuel emission factor. CF $\mathrm{A} 3 \mathrm{a}=(4.13 * 0.120)+(0.01416 * 10.277)=0.64$ $\mathrm{kg} \mathrm{CO}$ equiv/t

\section{Molding (A3b).}

$$
C F A 3 b=\left(C e^{*} F e e\right)
$$

Where. Ce: Unit electricity consumption, Fee: Electricity emission factor $\left(\mathrm{kgCO}_{2} / \mathrm{kWh}\right)$. $\mathrm{CF} \mathrm{A3b}=$ $(6.92 * 0.120)=0.83 \mathrm{CO}_{2}$ equiv $/ \mathrm{t}$

The results obtained refer to ton of product for its loading in the dryer.

\section{Drying (A3c).}

$$
C F A 3 b=\left(C e^{*} \mathrm{Fee}\right)
$$

Where: Ce: Unit electricity consumption, Fee: Electricity emission factor $\left(\mathrm{kgCO}_{2} / \mathrm{kWh}\right)$. Therefore, $\mathrm{CF} \mathrm{A} 3 \mathrm{c}=(180.00 * 0.120)=21.60 \mathrm{kgCO}_{2}$ equiv $/ \mathrm{t}$ 
The results refer to ton of dry product.

\section{Firing (A3d).}

$$
C F A 3 d=(C t * f c)+(C e * f e)
$$

Where: $\mathrm{Ct}=$ Thermal unit consumption $(\mathrm{kg}$ coal/ product ton $), \mathrm{fc}=$ fuel emission factor, $\mathrm{Ce}=$ Electric unit consumption, $\mathrm{fe}=$ Electric emission factor

$\mathrm{CF} \mathrm{A} 3 \mathrm{~d}=(83.33 * 2.81)+(10.80 * 0.12)=235.63$ $\mathrm{kgCO}$ equiv/t

\section{Classification and packaging (A3e).}

$$
C F A 3 e=(C e * F e e)
$$

In which, Ce: Unitary electricity consumption, Fee: Electricity emission factor $\left(\mathrm{kgCO}_{2} / \mathrm{kWh}\right)$. Therefore, $\mathrm{CF} \mathrm{A} 3 \mathrm{e}=(1.92 * 0.120)=0.23 \mathrm{kgCO}_{2}$ equiv $/ \mathrm{t}$

Carbon footprint of the manufacturing process with technological nutrient
Storage, loading and grinding (A3a). CF A $3 \mathrm{a}=$ $0.64 \mathrm{~kg} \mathrm{CO}_{2}$ equiv $/ \mathrm{t}$

Molding (A3b). CF A3b $=0.83 \mathrm{CO}_{2}$ equiv $/ \mathrm{t}$

Drying (A3c). CF A3c $=21.60 \mathrm{kgCO}_{2}$ equiv $/ \mathrm{t}$

Firing $(\boldsymbol{A} 3 \boldsymbol{d})$. In the case of firing, the results obtained in the study of energy consumption of the mixture of $90 \%$ clay and $10 \%$ fly ash, compared to the conventional process of manufacturing ceramic products ( $100 \%$ clay).

$\mathrm{CF} \mathrm{A} 3 \mathrm{~d}=220.05 \mathrm{kgCO}_{2}$ equiv $/ \mathrm{t}$. The results refer to ton of fired product.

Classification and packaging (A3e). $\mathrm{CF} \mathrm{A} 3 \mathrm{e}=$ $(1.92 * 0.120)=0.23 \mathrm{kgCO}_{2}$ equiv $/ \mathrm{t}$

\section{Global Results}

\begin{tabular}{|c|c|c|c|c|c|c|c|c|}
\hline \multirow{3}{*}{ PROCESS TYPE } & \multicolumn{8}{|c|}{ CF (kg CO2equiv/t) } \\
\hline & \multirow{2}{*}{ A1 } & \multirow{2}{*}{$\mathbf{A 2}$} & \multicolumn{5}{|c|}{ A3 } & \multirow{2}{*}{ TOTAL } \\
\hline & & & A3a & $\mathbf{A} 3 \mathbf{b}$ & A3c & A3d & $\mathbf{A} 3 \mathbf{e}$ & \\
\hline $\begin{array}{c}\text { Conventional } \\
(100 \% \text { clay })\end{array}$ & 2.95 & 1.94 & 0.64 & 0.83 & 21.60 & 235.63 & 0.23 & 263.82 \\
\hline $\begin{array}{c}\text { New alternative } \\
(90 \% \text { clay }+10 \% \text { nutrient })\end{array}$ & 2.67 & 1.91 & 0.64 & 0.83 & 21.600 & 220.05 & 0.23 & 247.93 \\
\hline
\end{tabular}

Table I. Results obtained for $\mathrm{HdC}$

It was applied in the same way as for clay, so the corresponding equations did not undergo any significant modification, except for the firing equation.

- Extraction (A1). CF A1 $=2.67 \mathrm{~kg} \mathrm{CO}_{2}$ equiv $/ \mathrm{t}$

- Transport of raw materials to plant (A2). CF A2

$=1.91 \mathrm{~kg} \mathrm{CO} 2$ equiv $/ \mathrm{t}$

Product manufacturing (A3)

\section{Assignment to declared unit}

To obtain the global value, each Carbon Footprint value has to be associated with the declared unit defined in the present investigation of "ton of finished product" (ceramic block manufactured in the brickyard). Therefore, the equivalence between the declared unit and the units to which the values of each of the studied phases are referred must be found. It is explained as follows:

\begin{tabular}{|c|c|c|c|c|c|c|c|c|}
\hline \multirow{3}{*}{ PROCESS TYPE } & \multicolumn{8}{|c|}{$\mathrm{CF}$ (kg CO2equiv/t) } \\
\hline & \multirow{2}{*}{ A1 } & \multirow{2}{*}{ A2 } & \multicolumn{5}{|c|}{$\mathbf{A 3}$} & \multirow{2}{*}{ TOTAL } \\
\hline & & & A3a & $\mathbf{A} 3 \mathbf{b}$ & $\mathbf{A 3 c}$ & A3d & A3e & \\
\hline $\begin{array}{c}\text { Conventional } \\
(100 \% \text { clay })\end{array}$ & 4.62 & 2.85 & 0.76 & 1.1280 & 23.52 & 240.44 & 0.23 & 273.54 \\
\hline $\begin{array}{c}\text { New alternative } \\
(90 \% \text { clay }+10 \% \text { nutrient })\end{array}$ & 4.18 & 2.80 & 0.76 & 1.12 & 23.52 & 224.54 & 0.23 & 257.16 \\
\hline
\end{tabular}

Table II. Assignment of values to declared unit 


\section{Results and Discussion}

The results, shown in the previous section, show that the environmental consequences of the addition of $10 \%$ of fly ash as a raw material in the manufacturing process of ceramic products are clearly positive.

Thus, the carbon footprint is reduced by 16.39 $\mathrm{kgCO}_{2}$ equiv/t finished product, which implies a decrease of $5.99 \%$ of the carbon footprint with respect to the conventional process. Extrapolating this reduction of carbon footprint to the ceramic production in the metropolitan area of Cucuta and considering a monthly production in the metropolitan area of Cucuta of 125750 tons of product/month, an emission savings of 2061.04 tons of $\mathrm{CO}_{2}$ would be obtained, and 24732.48 tons per year.

This saving is equivalent to the annual emissions of 2248.41 medium-sized homes that emit 11 tons of $\mathrm{CO}_{2}$ (according to data from the European Environment Agency), this value provides a good approximation of the environmental benefit of the new alternative process.

\section{Conclusions}

The results of the investigation show the environmental viability for the use of fly ash in the manufacture of ceramic products in the metropolitan area of Cucuta, as it reveals a reduction in the Carbon Footprint of the production process.

The firing stage of the product is the one that represents a greater decrease of Carbon Footprint. Other production stages do not suffer an alteration in terms of values. The drying stage is the one that presents a greater environmental impact, this is due to firing mass losses of the mixture with ashes with respect to the conventional mixture, which has their repercussion in the "upstream" stages, although the overall result is clearly favorable to the new alternative process.

Economically, the use of technological nutrient supposes an economic saving, from lower use of fuel, in the process of ceramic products manufacture.

The improvement implied by the new alternative process in the use of the technological nutrient as a raw material in the manufacture of ceramics contributes positively to the fulfillment of the sustainable development objectives of Colombia.

It is considered as a general conclusion, that the results are a contribution to identify and reduce the environmental impact the construction sector, from the perspective that the environmental impact of a building begins from the moment in which raw materials are extracted for the manufacture of construction products.

\section{References}

[1] N. L. Panwar, S. C. Kaushik y S. Kothari, "Role of renewable energy sources in environmental protection: A review" Renewable and Sustainable Energy Reviews, vol. 15, no. 3, pp. 1513-1524, 2011.

[2] K. M. Zhang y Z. G. Wen, "Review and challenges of policies of environmental protection and sustainable development in China," Journal of environmental management, vol. 88, no. 4, pp. 1249-1261, 2008.

[3] A.Al-Fakih, B. S. Mohammed, M. S. Liew y E. Nikbakht, "Incorporation of waste materials in the manufacture of masonry bricks: An update revieW," Journal of Building Engineering, vol. 21, pp. 37-54, 2019.

[4] N. Wang, Z. Guo, F. Meng, H. Wang, J. Yin y Y. Liu, "The circular economy and carbon footprint: A systematic accounting for typical coal-fuelled power industrial parks," Journal of cleaner production, vol. 229, pp. 12621273, 2019.

[5] M. Lieder y A. Rashid, "Towards circular economy implementation: a comprehensive review in context of manufacturing industry," Journal of Cleaner Production, vol. 115, no. 1, pp. 36-51, 2016.

[6] S. Abbas, M. A. Saleem, S. M. S. Kazmi y M. J. Munir, "Production of sustainable clay bricks using waste fly ash: Mechanical and 
durability properties," Journal of Building Engineering, vol. 14, pp. 7-14, 2017.

[7] N. G. Kulkarni y A. B. Rao, "Carbon footprint of solid clay bricks fired in clamps of India," Journal of cleaner production, vol. 135, pp. 1396-1406, 2016.

[8] L. A. Lett, "Las amenazas globales, el reciclaje de residuos y el concepto de economía circular," Revista Argentina de Microbilogía, vol. 46, no. 1, pp. 1-2, 2014.

[9] I. S. Jawahir y R. Bradley, "Technological Elements of Circular Economy and the Principles of 6R-Based Closed-loop Material Flow in Sustainable Manufacturing," Procedia CIRP, vol. 40, pp. 103-108, 2016.

[10] M. D. Bovea, E. Diaz-Albo, A. Gallardo, F. J. Colomer y J. Serrano, "Environmental performance of ceramic tiles: Improvement proposals," Materials \& Design, vol. 31, no. 1, pp. 35-41, 2010.

[11] J. Sánchez Molina, "Evaluación de los cambios en las propiedades térmicas y mecánicas del bloque \#5 fabricado en la región, según las mezclas entre arcilla y residuos industriales," Grupo de Investigación en Tecnologia Cerámica, UFPS, Cúcuta, Colombia, 2013.

[12] British Standards Institution, "PAS 2050:2001. Specification for the assessment of the life cycle greenhouse gas emissions of goods and services," BSI, London, 2011.

[13] International Organization for Standardization, "Greenhouse gases - Carbon footprint of products - Requirements and guidelines for quantification and communication" ISO, Geneva, Suiza, 2013.

[14] K. Diez-Contreras, J. Sánchez-Molina y D. Torres-Sánchez, "CHARACTERIZATION OF CLAY MATERIALS FROM THE SUBURB AREA OF CUCUTA, NORTH OF SANTANDER, COLOMBIA FOR CERAMIC APPLICATION," de XXVI
INTERNATIONAL MATERIALS RESERCH CONGRESS, Cancun, Mexico, 2017.

[15] Asociación Española de Normalización y Certificación, "Reglas de producto".

[16] TBE PCR FOR CLAR CONSTRUCTION PRODUCTS, "Guidance document for developing an EPD. Tiles \& Bricks Europe aisbl," Tiles Bricks, 2014.

[17] Instituto Colombiano de Normas Técnicas, "NTC 6033. Etiquetas ambientales tipo I. Sello ambiental Colombiano (SAC) Criterios ambientales para ladrillos y bloques de arcilla," INCONTEC, Bogotá, 2013.

[18] Normalización Española, "UNE EN 15804:2012. Sustainability of construction works - Environmental product declarations - Core rules for the product category of construction products," Normalización Española, Madrid, 2012. 